\begin{tabular}{|c|c|}
\hline Title & Fostering Self-A uthorship Through W ork Integrated Learning in University Tourism Programs: A Missed Opportunity? \\
\hline Author(s) & Caldicott, Julia; Wilson, Erica; Donnelly, James F.; Edelheim, Johan R. \\
\hline Citation & $\begin{array}{l}\text { Journal of hospitality and tourism education, 32(4), 220-233 } \\
\text { https://doi.org/10.1080/10963758.2019.1685891 }\end{array}$ \\
\hline Issue Date & 2019-11-14 \\
\hline Doc URL & http:/hdl.handle.net/2115/81332 \\
\hline Rights & $\begin{array}{l}\text { This is an A ccepted Manuscript of an article published by Taylor \& Francis in Journal of Hospitality \& Tourism } \\
\text { Education on } 14 \text { November 2019, available online: } \\
\text { https:/Www.tandfonline.com/doi full/10.1080/10963758.2019.1685891. }\end{array}$ \\
\hline Type & article (author version) \\
\hline File Information & $\begin{array}{l}\text { Caldicott, Wilson, Donnelly \& Edelheim, } 2019 \text { - Fostering_Self-A uthorship Through W ork Integrated Learning in } \\
\text { University_T ourism Programs- A Missed Opportunity, pre pub version.pdf }\end{array}$ \\
\hline
\end{tabular}

Instructions for use 
Fostering self-authorship through Work Integrated Learning in university tourism programs: A missed opportunity?

Julia Caldicott ${ }^{\mathrm{a} *}$, Erica Wilson ${ }^{\mathrm{b}}$, James F. Donnelly ${ }^{\mathrm{c}}$ and Johan R. Edelheim $^{\mathrm{d}}$

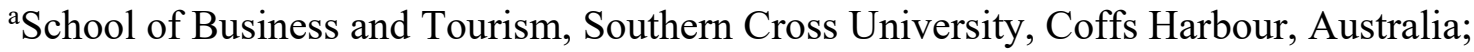
(Orcid https://orcid.org/0000-0001-6463-1141)

${ }^{b}$ School of Business and Tourism, Southern Cross University, Lismore, Australia; (Orcid https://orcid.org/0000-0003-4768-3251)

'Psychology, School of Health and Human Sciences, Southern Cross University, Coffs Harbour, Australia;

(Orcid https://orcid.org/0000-0002-2052-7948 )

and

${ }^{\mathrm{d}}$ Graduate School of International Media, Communication, and Tourism Studies, Hokkaido University, Sapporo, Japan.

d Faculty of Social Sciences', University of Stavanger, Stavanger, Norway. (Orcid https://orcid.org/0000-0002-4183-5931 )

* Julia Caldicott

Lecturer

Work Integrated Learning (WIL) Coordinator

School of Business and Tourism

Southern Cross University

Coffs Harbour Campus

Hogbin Drive, Coffs Harbour NSW 2450

Phone: 0266593620

Email: Julia.caldicott@scu.edu.au 


\section{Fostering self-authorship through Work Integrated Learning in university tourism programs: A missed opportunity?}

Work integrated learning (WIL), in its various forms, continues to be a central element of university tourism programs. Internships, the most common form of WIL, provide opportunities for both personal and professional development. This article presents findings of a content analysis of WIL programs in Australian tourism, hospitality and events (TH\&E) undergraduate degrees. Publicly available unit/subject guides were gathered through an internet-based review. This analysis of secondary data identified that the majority of WIL curricula in the Australian university TH\&E programs focus on career development, followed by academic achievement and thirdly, personal development. It is argued that the opportunity to facilitate students' personal growth and the achievement of advanced learning outcomes through WIL is not being fully realised. Through the lens of 'self-authorship', meaning in this case, the student's use of their internal voice to guide their beliefs, identity and relationships, this paper explores the opportunities for WIL programs to be (re)designed to meet industry needs while also facilitating the individual, personal development of future tourism, hospitality and events leaders.

Keywords: work integrated learning, self-authorship, university tourism degrees, Australia

\section{Introduction}

With an ever growing need for skilled employees, the tourism and hospitality industries rely on the capabilities of graduates from university tourism and hospitality programs. In Australia and New Zealand, where the tourism and hospitality industries make a 
significant contribution to their national economies, current labour shortages have been noted and continued future shortages have been predicted (Deloitte, 2015; Poulston \& Jenkins, 2016). Whilst a university qualification is not mandatory for many roles in these industries (Airey, Tribe, Benckendorff, \& Xiao, 2015), the increased number of university programs offering tourism and hospitality education over the past 40 years has meant that universities are now an important stakeholder in the tourism and hospitality workforce.

Research has identified a lack of agreement about what different stakeholders seek in a hospitality degree. An analysis of research investigating the expected learning outcomes of hospitality higher education graduates demonstrated a divergence depending on the perspectives of the major stakeholder groups namely; students, graduates, industry and educators (Gross, Benckendorff, Mair \& Whitelaw, 2017). Literature reporting on student perspectives identified the desire to be well prepared for future careers through technical skill acquisition during their hospitality degree (Frawley, Goh \& Law 2019; Gross et al., 2017; Richardson 2009). Research on graduate perspectives reported an imbalance of practical curriculum areas over more liberal reflective skills (Gross et al., 2017; Sisson \& Adams 2013). Industry perspectives were mixed with some research demonstrating industry criticism of hospitality graduates lacking appropriate vocation-specific capabilities, while others criticise graduates for shortcomings in more liberal, reflective areas (Gross et al., 2017). Studies focusing solely on educators' perspectives of what should constitute a tourism and hospitality higher education program were deemed to be lacking (Gross et al., 2017). How tourism and hospitality curricula prepare graduates to be 'industry-ready' and 'work-ready' continues to be an important consideration for academic institutions 
seeking to make their programs attractive and relevant to students and in line with industry requirements.

Over the past two decades there has been a growing concern amongst scholars that there needs to be a balance of liberal and vocational education in tourism and hospitality programs (Belhassen \& Caton, 2011; Dredge, Benckendoff, Day, Gross, Walo, Weeks \& Whitelaw, 2012a). A liberal education can develop the students' capacity to confront problems and think creatively, and also prepare learners to be freethinking citizens (Dredge et al., 2012a). Whilst tourism graduates must possess significant practical skills to appeal to industry employers (Wang, Ayres, \& Huyton, 2009), there is increasing support for a curriculum that produces 'philosophic practitioners' (Tribe, 2002), who could develop their own prosocial values. As they respond to the needs of the tourism and hospitality industries, they would be reflective individuals who are capable of questioning the industries' social responsibilities (Inui, Wheeler \& Lankford, 2006).

In 2007, The Tourism Education Futures Institute (TEFI) was established to "provide vision, knowledge, and a framework for tourism education programs that promote global citizenship and optimism for a better world" (Sheldon, Fesenmaier \& Tribe 2011, p. 2). The goal of TEFI is transformational change in tourism education, to produce graduates that become responsible stewards who guide tourism development. Additionally, the 'critical turn' in tourism inquiry which challenges the dominant postpositivist approaches and locates the phenomenon of tourism within its political, social, economic and cultural contexts (Ateljevic, Pritchard \& Morgan, 2007), is exerting influence on tourism education. Many argue that curricula and pedagogy which provide diverse theoretical and applied knowledge that enhances an understanding of the 
complexities of tourism and hospitality experiences are required to educate our future tourism leaders (Cockburn-Wootten \& Cockburn, 2011; Dredge et al., 2012a).

Despite concern about the over-emphasis on 'vocationalism' and considerable interest in Tribe's alternative philosophical practitioner model in the academic community (Belhassen \& Caton, 2011; Dredge et al., 2012a; Inui et al., 2006), Ring, Dickinger and Wöber (2009) highlighted the lack of a liberal social science component in university tourism programs. In their review of 64 undergraduate tourism programs, only 6 percent were found to feature a significant liberal component. It has been suggested that such reluctance is due to university decisions about program curricula being affected by neoliberal funding models (Connell, 2013), a focus on employability (Barnett, 2009; Peach \& Matthews, 2011) and the traditional purpose of tourism and hospitality education being the preparation of employees for the workplace (Catrett, 2018; Connolly \& McGing, 2006). The dominant discourse in tourism higher education remains that tourism is an 'industry', or a collection of industries (Dredge, Schott, Daniele, Caton, Edelheim \& Munar, 2015; Higgins-Desbiolles, 2006) hence universities are skilling students as human capital for this workforce (Holborow, 2012; Johnston, 2011). In addition to these economic priorities, critics of tourism education called for future tourism leaders and practitioners to also be cognizant of the transformative potential of tourism as a social force (Higgins-Desbiolles, 2006).

Tourism and hospitality have been recognised as world-making activities because they have a "creative and transformative role in the making of people and places and in the production of meanings, values and understandings about the past, present and future" (Dredge et al., 2012a, pp. 2159-2160). Accordingly, there is growing recognition of the need for universities to provide tourism curricula that balance the needs and demands of industry, whilst equipping graduates with the 
knowledge, skills and practical wisdom to act ethically and responsibly in their worldmaking roles (Dredge et al., 2012a; Sheldon, Fesenmaier \& Tribe, 2011; Tribe, 2002).

Tourism and hospitality university education has long recognised the importance of an experiential component (Catrett, 2018; Gibson \& Busby, 2009). This workplacebased component is variously referred to as work-integrated learning (WIL), an internship, an industrial placement, a work placement, cooperative education or a practicum. Commonly regarded as a strategy to equip learners with the required practical skills for the workplace, WIL may also provide opportunities to interpret and integrate their workplace experiences with academic concepts (Cooper, Orrell \& Bowden, 2010; Farmaki, 2018; Wang, Kitterlin-Lynch \& Williams, 2018).

Consequently, WIL programs have the potential to bridge liberal and vocational education, overcoming the need for a trade-off between knowledge and skills, a challenge frequently discussed in relation to tourism and hospitality higher education curriculum design (Busby, 2003; Dredge, et al., 2012a).

Given the growing recognition of the need for changes to tourism and hospitality education, consideration of how liberal education experiences can be integrated into existing tourism and hospitality programs is warranted. Despite the vocational or skillacquisition nature of most WIL programs, this component of a tourism and hospitality degree provides unique opportunities for a pedagogy that helps learners think about the uncertainties and dilemmas required for living in a world characterised by 'supercomplexity', uncertainty, and future change (Barnett, 2002). Given that students are at the centre of the learning experience in what can be challenging WIL placements, there is ample opportunity for engendering critical thinking and self-reflection.

Curricula and pedagogy that focus on personal growth may foster selfauthorship. Self-authorship - the capacity to internally generate beliefs, identity and 
social relationships (Kegan, 1994), has been linked to a young adult's success in complex work, educational and personal environments (Baxter Magolda, 2009; Torres, 2010). Developing self-authoring capacities in identity, relationships and knowledge during higher education reportedly provides a foundation for mature adult decisionmaking, and effective interdependent relationships and citizenship (Baxter Magolda, 2009). Arguably, self-authored graduates would be well placed to be the ethical and agile tourism leaders that the global tourism, hospitality and event industries require. Additionally, being self-authored may empower graduates to make meaningful adjustments in their future workplaces and impact on the reported high turnover in the tourism and hospitality industries.

\section{Research Gaps and Research Aims}

Despite WIL being a common feature of tourism and hospitality university programs, studies specifically examining the curriculum of WIL units in these programs are sparse. The main purpose of this study was to identify the current focus of WIL units in tourism, hospitality and event (TH\&E) undergraduate degrees in Australia. Analysing the unit content, description and expected student learning outcomes of WIL units rendered insights into what Australian TH\&E education providers see as the current role of this degree component. Additionally, the study aimed to inform the design of WIL programs so they foster students' self-authorship development, equipping them for complex challenges in the tourism sector and life in general. Whilst other units in tourism and hospitality degrees potentially incorporate curricula and pedagogical strategies that might promote self-authorship development, this current study analysed WIL units only. Exclusively reviewing WIL units reflects the widespread inclusion of WIL in Australian tourism and hospitality university programs 
and the unique characteristics of WIL units which could foster self-authorship development.

This paper also aims to add to the paucity of TH\&E education research identified by an analysis of tourism related journal articles in 2009 (Ballantyne, Packer \& Axelsen, 2009) with the trend still reportedly continuing (Goh, Nguyen \& Law, 2017; Hsu, Xiao \& Chen, 2017). Limited research was found to specifically analyse the curriculum of WIL units in tourism and hospitality education from the educator's perspective, with notable exceptions being Busby's (2003) and Yiu and Law's (2012) contributions. Furthermore, Baum, Kralj, Robinson and Solnet's (2016) exposé on the under-representation of tourism and hospitality workforce research highlights the need for further understanding of the role of TH\&E education in meeting the demands of individual students and the workplaces they may enter upon graduation.

\section{Literature Review}

\section{Work Integrated Learning}

Work integrated learning (WIL) is now a common component of university curricula for many disciplines. A frequently cited definition refers to WIL as "an umbrella term for a range of approaches and strategies that integrate theory with the practice of work within a purposefully designed curriculum" (Patrick, Peach, Pocknee, Webb, Fletcher \& Pretto, 2008, p. iv). The concept of WIL is not new, but the employability agenda being pursued by many universities has resulted in a notable increase in WIL and other 'workready' programs (Orrell, 2011; Palmer, Young \& Campbell, 2018; Rowe \& Zegwaard, 2017; Smith \& Worsfold, 2014). However, WIL is differentiated from other forms of learning in the workplace such as work-based learning, including apprenticeships where the learning occurs almost exclusively in the workplace, and work experience, which is 
generally an exploratory and observational activity for secondary students seeking insights into career directions (Cooper et al., 2010). The distinctive characteristics of WIL include intentional learning situated in the workplace leading to integration of theory and practice (Cooper et al., 2010, italics in original).

Much of the literature regarding WIL attests to the benefits of the tripartite relationship among the educational institution, the employer and the student (Farmaki, 2018; Natoli, Jackling, Kaider \& Clark, 2013). Additionally, there is recognition that work integrated learning, and education generally, should address societal needs not just those of employers (Coll \& Eames, 2004). WIL provides students with opportunities for professional development, but also for personal development (Gribble, Dender, Lawrence, Manning, \& Falkmur, 2014; Orrell, 2011; Simpson, Thyer, Van Nugteren, Mitchell, \& Werner, 2016). Billett (2008) notes that the focus of WIL need not be only on canonical and situational knowledge, but also be recognised as a stimulus for overall personal development. Similarly, Choy $(2009$, p. 66) noted that WIL offers the "potential for transformational learning in the workplace, and it facilitates a sociocultural experience that shapes interpretations, meaning schemes, and knowledge formation".

To examine the potential positive effects of WIL, research into student outcomes has been prolific in the past 30 years. Fletcher (1989) initially identified three clusters of outcomes related to participation in WIL (also known as Cooperative Education): career development, career progress and personal growth. They were later revised by Fletcher (1991) to personal development, career development and academic achievement. Fletcher's (1991) model was used by Parks and colleagues (2001) to develop a measure for Predicting Learner Advancement through Cooperative Education (PLACE). 
The PLACE instrument (Parks et al., 2001) incorporated industry and accreditation-driven parameters to identify four categories of student outcomes: (1) career development: (2) academic functions/achievement: (3) work-skills development; and (4) personal growth/development. Dressler and Keeling's (2011) review of the cooperative education literature categorised studies of student outcomes into four competency areas related to the PLACE instrument including academic, personal, career and work skill development benefits. However, it is argued here that work skill development and career development can be considered together given the extrinsic, employability focus of competencies within these categories. Consequently, Fletcher's (1991) three categories of student outcomes from cooperative education was used in the current study.

\section{Work Integrated Learning in TH\&E}

University tourism, hospitality and event management programs have a long history of incorporating WIL into their degrees (Gibson \& Busby, 2009; Yiu \& Law, 2017). The WIL component is frequently compulsory and includes various experiences working in a related industry sector. Tourism and hospitality WIL programs can be paid or voluntary, and undertaken domestically or internationally. The amount of academic credit accrued during a WIL program varies among institutions, as does the level of institutional involvement in the management, administration and supervision of WIL placements. Rarely do tourism and hospitality WIL programs have the professional accreditation requirements of other disciplines such as nursing, engineering and education (Baker, Caldicott \& Spowart, 2011).

The tourism and hospitality industries are noted for difficulties in attracting and retaining well suited employees (Francis \& Alagas, 2017; O’Driscoll, 2012; Richardson, 2008; Solnet \& Hood, 2011). Tourism and hospitality careers are purportedly fast 
paced, exciting, dynamic, and provide the opportunity to travel and meet new people (Solnet \& Hood, 2011), yet the challenges that come with these careers are also well documented. The negative aspects of a career in tourism and hospitality reportedly include low pay, irregular and anti-social hours, hostile workplace cultures, lack of training and development, unjust promotional systems and high emotional labour requirements (Chua, Bakerb \& Murrmannc, 2012; Cockburn-Wootten, 2012). In a study of tourism students' perceptions of the industry more than 50 percent reported that they were contemplating careers outside of the industry and most cited work experience in the industry as the main reason for this decision (Richardson, 2008). Similarly, Raybould and Wilkins (2005) note that many hospitality graduates leave the industry because of unfulfilled expectations. Consequently, the dominant discourse in tourism and hospitality WIL literature is the need for higher education providers to work collaboratively with industry to manage learners' expectations, with the aim of increasing graduate employability and industry retention (Lam \& Ching, 2007; Lee \& Dickson, 2010; Richardson, 2009; Stansbie \& Nash 2016; Yiu \& Law, 2012; Zopiatis \& Theocharous, 2013).

Tourism and hospitality research has identified a number of differences in those students who complete WIL programs including stronger career intentions (Busby, 2003; Silva, Lopes, Melo, Dias, Brito \& Seabra, 2016); increased employability in relevant positions after graduation (Purcell, 1999 cited in Busby, 2003); and faster advancement opportunities than their non-WIL counterparts (Harper, Brown \& Irvine, 2005). A key benefit to tourism and hospitality industries is the correlation between learners who have participated in highly structured WIL programs and increased industry retention (Dickerson \& Kline, 2008). However, as noted above, other studies have highlighted that familiarity with the hospitality industry was a major reason that 
individuals left the industry (Richardson, 2008; Robinson, Ruhanen \& Breakey, 2015; Teng, 2008). Arguably, the success of the WIL placement is dependent on the curricula and pedagogic practices of the WIL program that influence learners' expectations and their subsequent clash with reality.

Unfortunately, significant negative experiences during tourism and hospitality internships (Siu, Cheung \& Law, 2012) or discrepancies between expectations and satisfaction are typical in learner comments (Farmaki, 2018; Lam \& Ching, 2007; Leslie \& Richardson, 2000; Raybould \& Wilkins, 2005). Poor communication, unsatisfactory interpersonal relations and lack of knowledge to perform required tasks, as well as psychological distress, frustration and depression have been reported following tourism and hospitality internships (Lam \& Ching, 2007) and after short times in the industry (Richardson, 2008). It is therefore not surprising that many authors suggest that improving the WIL experience will address these concerns and result in more graduates choosing to remain in the industry (Farmaki, 2018; Lam \& Ching, 2007).

\section{Self-authorship}

Against the backdrop of the current skills-based, employability agenda of the higher education sector, calls have been made for a greater emphasis on holistic student development to better prepare students for their transition from university to the professional world. Such a holistic approach sits in opposition to a curriculum focused on technical or procedural knowledge (Barnett, 2000; Kumar, 2007). A curriculum which includes a focus on students' personal development has the ability to foster selfauthorship; the development of an internal voice to navigate life's challenges (Baxter Magolda, 2009).

Originally coined by Kegan (1982), the term 'self-authoring' refers to a stage of self-evolution reached by progressing from reliance on others (for example teachers, 
peers and parents) to taking responsibility for one's own meaning making. Kegan (1982) proposed that humans make meaning from their perceptions through three major dimensions, namely: cognitive (how we come to know); intrapersonal (how we view our identities) and interpersonal (how we construct our relationships). As humans develop, Kegan argues, they move through five stages of increasingly complex ways of knowing. Over the years Kegan has named these as stages of development (1982); orders of consciousness (1994) and forms of mind (2000). The first two stages are experienced by children, with most individuals reaching the third stage in adolescence. The self-authoring mind is the fourth stage which is often reached in the late $20 \mathrm{~s}$, and the final stage in Kegan's (1994) stages of development is the self-transforming mind which does not develop until mid-life, if at all.

Baxter Magolda (2009) is credited with substantially advancing the concept of self-authorship, based on her twenty-five-year longitudinal study of college students' learning and development. Her findings affirmed Kegan's (1994) proposition that personal growth occurs as a developmental process from an external definition to an internal definition. Whilst individuals use unique and different ways of dealing with challenges, Baxter Magolda (2009) identified four common phases which young adults (aged between 18-40 years) progress through as they move towards, and into selfauthorship. In the first phase, following external formulas, individuals rely on others for what to believe in and how to succeed. Individuals tend to reach the crossroads phase when they encounter a situation which forces them to question the external formulas which they had previously relied on. Becoming self-authored occurs when individuals recognise that knowledge, self, and relationships all develop and exist in the context of others; cultural norms lead to the construction of new answers that are internally defined. Internal foundations, the final phase of self-authorship (being the author of 
one's life), is reached when an individual develops an internal voice to guide their beliefs, and inform their identity and the meaning of relationships (Baxter Magolda, 2009).

According to Baxter Magolda (2009) the expected core outcomes of most Western higher education programs include effective citizenship, critical thinking, complex problem solving, interdependent relations with diverse others and mature decision-making. Such overarching higher education outcomes require informational learning (that is, knowledge and skills) and transformational learning, where an individual acts on his/her own values, feelings and meanings rather than those that they have uncritically assimilated from others (Baxter Magolda, 2009; Kegan, 2000; Mezirow, 2000). Cognitive (knowing), intrapersonal (identity) and interpersonal (relationship) developmental capacities are required for transformational learning (Kegan, 2000). The expectations on young adults in higher education and contemporary society in general, may therefore exceed their current meaning-making capacities (Baxter Magolda, 2009; Kegan, 1994). Developing self-authoring capacities during higher education reportedly provides young adults with a foundation for more mature adult decision-making, interdependent relationships and effective citizenship (Baxter Magolda, 2012).

The current investigation attempted to characterise the wide range of WIL programs in university TH\&E programs and to determine to what degree self-authorship or other personal development features were included in units or WIL experiences.

\section{Methods}

\section{Sample}

This study examined the WIL units in tourism, hospitality and event (TH\&E) 
undergraduate degrees offered by Australian universities in 2015. In the data capture period $25(60 \%)$ of Australia's 42 public and private universities offered TH\&E full undergraduate degrees. Excluded from this analysis are the private higher education providers that also offer bachelor degrees in TH\&E, but are not part of comprehensive public or private universities, rather being specialised colleges with a limited range of educational offerings. These were excluded since private providers more clearly purport to offer employability as one of their main outcomes rather than the liberal education aims that universities claim to pursue.

The degree was deemed to be a TH\&E degree if it contained the word tourism, hospitality and/or event(s) in the title of the degree or the title of the major. The list of TH\&E providers outlined by Dredge, Benckendoff, Day, Gross, Walo, Weeks and Whitelaw (2012b) was used and also cross-checked with the Universities Australia website. Table 1 lists the university and the name of the TH\&E degree offered. Double degrees were not included in the study since the tourism components of the double degree were captured by including the single tourism degree from the given institution. Undergraduate associate degrees and postgraduate qualifications were not considered in this study.

[Table 1 near here]

\section{Data collection}

Publicly available unit (subject) information guides for all TH\&E programs that contained WIL units were accessed from the websites of the relevant universities. Variations of what the different universities included in their unit information guides was apparent and consequently the data from each was not equal. In an attempt to create a more complete data set the analysis focused on the unit descriptions, content and learning outcomes rather than solely on the learning outcomes. Content analysis of the 
phrases in these three sections of the unit information guide was used to identify the focus of WIL units in Australian university TH\&E curricula.

\section{Data analysis}

Content analysis is a commonly used method allowing for the examination of the data as a whole, with themes identified across the data and grouped through a coding system (Mayring, 2004). Notable content analyses of TH\&E curricula within the Australian context exist. Wang, Ayres and Huyton (2010) study of Australian tourism programs identified 7 broad categories of subjects within TH\&E education. More recently Dredge et al. (2012b) pursued a comprehensive curriculum mapping study of TH\&E programs across Australian universities. Robinson, Breakey and Craig-Smith's (2010) research focused specifically on the food and beverage content of Australian university TH\&E curricula. A national review of WIL programs in TH\&E curricula in Australia was lacking.

To determine the focus of WIL units, phrases were counted each time they occurred in the relevant section of the unit information guide. Initially, data regarding each of the WIL units was entered into an Excel spreadsheet. When available, such data included name of institution, type of faculty, name of degree program, name of WIL unit, type of WIL (placement, project), core or elective, level of unit (e.g. introductory, sandwich, capstone), amount of academic credit, assessments, work placement time requirement, unit description, unit content and unit learning outcomes. Latent coding was required to look for the underlying implicit meaning in the relevant sections of unit information guides (Neuman, 2011). After careful coding of all relevant content, a frequency analysis was conducted to identify themes which were then categorised into one of Fletcher's (1991) three categories relating to student learning outcomes: 1) 
personal, 2) career and 3) academic. Interpretation of the implicit meaning in the phrases was necessary given the different terms used within the texts and the intended purpose of the unit information guides. As Busby and Fiedel (2001) have noted sometimes course prospectuses are used by universities for promotional purposes and the information can be written in imprecise terms.

The inherent subjectivity of interpreting phrases was reduced by analysing the data in all three sections when available. For example, the phrase 'encouraging selfreflection' in a unit description was categorised in the theme 'reflection on the learning process' and noted as belonging in the 'academic achievement category'. The text in the corresponding unit content section of this unit information guide elaborated that the self-reflection was in regards to reflecting on one's abilities to apply skills from academic studies to the business world. This phrase, therefore, was interpreted as relating to the academic achievement category rather than the personal development category since it was not deemed to relate to self-reflection in the sense of reflecting on one's values or identity.

\section{Findings}

In the data capture period of $2015,39 \mathrm{TH} \& \mathrm{E}$ degrees were offered across these 25 universities. The majority, or $31(80 \%)$ of all TH\&E degrees, were offered through business/management faculties. Education and humanities faculties accounted for 7 $(18 \%)$ of all TH\&E degrees, whilst one degree $(2 \%)$ was situated in an environmental science faculty.

\section{Tourism undergraduate degrees incorporating WIL}

University tourism degrees often incorporate a work integrated learning component (Gibson \& Busby, 2009). Thus not surprisingly, the analysis revealed that 32 (82\%) of 
all Australian TH\&E degrees offered WIL units/subjects in 2015. Of these 32 degrees, 20 contained some form of WIL as core/compulsory units. All but one of these degrees provides academic credit for such WIL. Consequently, $51 \%$ of all undergraduate TH\&E degrees offered by Australian universities contain compulsory WIL units.

In 2015, across these Australian TH\&E undergraduate degrees, a total of 54 WIL units were offered. As outlined above there are different forms or types of WIL including internships, practicums, clinical placements, volunteering, case studies, community programs, fieldwork, role plays, simulations and virtual projects. Consistent with the literature (Orrell, 2011) the majority of units (34) were off-campus placement based units, accounting for $63 \%$ of all WIL units offered. Eight units were project based whilst 7 of the WIL units would be classified as placement preparation units. Two units were field trip based WIL units. The remaining three identifiable categories included simulations (1 unit); a unit combining preparation and placement activities (1 unit) and a miscellaneous unit which involved a variety of WIL related activities such as a short placement, related project and assessments (1 unit).

The analysis identified that just over half (28 units; 52\%) of the WIL units were capstone in nature; being noted as 'advanced', 'restricted to final year' and/or 'requiring completion of two thirds of the degree'. The remaining 26 units were situated in the introductory or intermediate years of the undergraduate programs. The majority of the WIL units in the study were graded. In total, 39 units (72\%) were 'graded'; 4 units were identified as 'ungraded' and for the remaining 11 units this information was not specified. For the placement-based WIL units, the required number of placement hours varied greatly between the degrees. The requirement ranged from 1 day/week for 13 weeks as the minimum to 6 months full-time (for a double-weighted unit). A small 
number of degrees did not specify the required placement hours in the publicly available information.

\section{Focus of tourism WIL units}

\section{Unit description}

Of the 54 tourism WIL units offered by Australian universities, all 54 unit descriptions were publicly available. As the name suggests, the unit descriptions in unit information guides or webpages are generally one paragraph statements which provide a general overview of the content studied in the unit combined with an overview of the teaching approach employed within the unit. From the 291 phrases used in the unit descriptions a number of key themes emerged. Table 2 outlines those themes with 10 or more occurrences in the unit descriptions. The most prominent themes identified in the unit descriptions were 'career related' (mentioned 48 times), 'application of knowledge and skills to practice' (mentioned 42 times), 'authentic' (mentioned 36 times) and 'acquire professional attitudes' (mentioned 31 times). The characteristics that were rarely mentioned included: independent thinking; initiative; curiosity; enthusiasm; resourcefulness; consolidate past learning; cross disciplinary contexts; experiential learning; and complemented by a rigorous academic program.

[Table 2 near here]

When categorising all themes from the unit descriptions it is evident that career development is the dominant focus of tourism WIL units offered by Australian universities. The analysis identified that $58 \%$ of the themes related to career development, $24 \%$ to academic development, and $18 \%$ to personal development. Career development encompassed themes such as: career related; authentic; culturally 
competent; acquiring professional attitudes; competent; project and placement. Themes relating to academic achievement included: application of knowledge and skills to practice; reflection on learning process; acquire knowledge; acquire research skills; independent thinking; consolidate past learning; and complemented by a rigorous academic program. The personal development category was represented by themes such as: team work; self-awareness; develop generic skills; feedback; ethical; leadership and autonomy; creativity; initiative; curiosity; enthusiasm; and resourcefulness.

\section{Unit content}

Not all universities detailed the unit content of their WIL units on their websites. In total, the unit content statements of 32 WIL units were analysed. From these statements 233 phrases were identified. From the 233 phrases used in the unit content statements a number of key themes emerged. Table 3 outlines those themes with 10 or more occurrences in the unit descriptions. The most prominent themes identified in the unit content were 'careers/employability' (mentioned 41 times), 'professionalism/professional practice' (mentioned 20 times), 'communication' (mentioned 17 times) and 'reflection on performance (mentioned 16 times). The characteristics that were rarely mentioned included: 'citizenship'; 'identifying a business problem'; 'existing workplace'; 'power and influence' and 'research methods'.

[Table 3 near here]

Similar to the unit descriptions, the content statements for the WIL units emphasised a focus on career development. In the unit content statements, $56 \%$ of the identifiable themes could be classified as relating to career development. A further $25 \%$ related to academic development, and 19\% were regarding the students' personal 
development. Career related themes included: 'careers/employability'; 'professionalism/professional practice'; 'workplace planning/management'; and 'authentic professional environment'. Themes relating to a student's academic development included: 'reflection on performance'; 'application of coursework to practice'; 'critically evaluate' and 'experiential learning'. Personal development was depicted by themes such as: 'communication'; 'collaboration/team work' and 'selfawareness'.

\section{Unit learning outcomes}

Learning outcomes are a common feature of unit information guides. As the name implies, unit learning outcomes are specific statements of what students are expected to learn in a unit and to be able to demonstrate at its completion (Macquarie University, 2019). The unit learning outcomes for 31 of the 54 WIL units reviewed in this study were publicly available. Table 4 lists the top themes identified in the unit learning outcomes of these 31 units. In total 151 phrases were mentioned. The most common themes in the learning outcome statements included: 'professional conduct/development'; 'career'; 'applying discipline specific knowledge to practice'; 'reflection'; 'communication' and 'business environment awareness'. Phrases which were rarely mentioned in the unit learning outcomes included: 'expanding/gaining knowledge'; 'capacity to work effectively'; 'cross cultural appreciation'; 'ambassadors'; and 'industry liaison'.

[Table 4 near here]

Consistent with the themes identified in the unit descriptions and the content statements, the unit learning outcomes for the WIL units depicted an emphasis on career development. The analysis identified that $50 \%$ of the learning outcome themes were 
related to career development. Such themes included: 'professional conduct/development'; 'career' and 'business environment awareness'. Almost one third (31\%) of learning outcome themes related to academic achievement. Themes in this category included: 'applying discipline specific knowledge to practice'; 'reflection'; 'evaluating the relationship between theory and practice' and 'research skills'. Themes such as: 'communication'; 'initiative/decision making'; 'self-awareness/selfmanagement' and 'working with others' were identified as personal development learning outcomes. Nineteen $(19 \%)$ of the learning outcomes for the WIL units related to personal development.

\section{Discussion and Conclusions}

This current study makes empirical contributions to the literature on the composition of tourism and hospitality university education. Specifically, the study identified the focus of WIL units in tourism, hospitality and event undergraduate degrees offered by Australian universities. The content analysis of publicly available unit information guides of 54 WIL units in TH\&E undergraduate degrees, offered by Australian universities, indicated that the focus of these units was predominantly career development, followed by academic achievement and then, lastly, personal development. This orientation in all three sections of the unit information guide is perhaps not unexpected given the desired alignment between descriptions, content and learning outcomes when designing units.

These findings support those of previous studies (Airey \& Johnson, 1999; Busby \& Fiedel, 2001); university tourism programs continue to be dominated by vocational concerns. Widely recognised as a strategy for equipping students with employability skills, it is not surprising that WIL placements are still common features of TH\&E programs offered by Australian universities. However, given the unique learning 
environment that WIL provides and the recognition that WIL can bridge the vocational and liberal goals of education, this study highlights a missed opportunity.

Future tourism practitioners and leaders will need to be personally robust to succeed in times of uncertainty. WIL programs that equip students with the capacity to manage complexity, uncertainty and change in their workplaces and the world in general, may assist them as they transition from their university studies. The analysis identified themes that were rarely mentioned in the unit information guides and therefore presumably deemed to be of little importance in relation to the student learning outcomes of the WIL units. These were independent thinking; initiative; curiosity; citizenship; capacity to work effectively and cross-cultural appreciation. Admittedly, these competencies may be fostered in different units in a TH\&E degree, but arguably these are all well suited to being developed when students are challenged by an unfamiliar yet career-relevant setting such as a WIL placement.

Continuing to design programs with such an over-emphasis on career development has evidently not stemmed the flow of many graduates from the tourism and hospitality industries. Frequently cited negative experiences during industry internship placements (Siu, Cheung \& Law, 2012), or upon entering the workforce as a graduate, could be explained by students experiencing the crossroads stage of selfauthorship development. Students leaving higher education and entering the workforce often experience situations where there are multiple competing perspectives, expectations and possibilities and no clear formula to guide their decisions (Pizzolato, 2005). Feelings of dissatisfaction of following externally defined formulas, such as advice of a parent or the directions from a workplace supervisor are common (Johnson, 2013; Pizzolato, 2005). Trusting their own internal voice rather than consistently and 
unquestioningly relying on external sources, self-authored graduates may feel empowered to make informed decisions in their working lives.

\section{Implications for practice}

Studies have identified that higher education which focuses on knowledge and intellect is insufficient for mature adult functioning; required in life after college/university (Baxter Magolda, 2012). WIL programs with a focus on personal development could foster student self-authorship and equip these young adults more effectively for functioning in real world settings (Baxter Magolda, 2009). Some existing research indicates that self-authorship development can be fostered by intentionally designed pedagogy during university. The Learning Partnership Model (Baxter Magolda, 2012) is showing promise in fostering progression towards self-authorship and has potential applicability for WIL programs in TH\&E education.

Whilst not prescriptive, Baxter Magolda's (2004, 2009, 2012) Learning Partnership Model (LPM) outlines three supportive components and three challenges in the learning environment that educators can provide in order to promote self-authorship development. Support is provided through three principles:

1) Respecting learners' thoughts and feelings, thus affirming the value of their voices;

2) Helping them view those experiences as opportunities for learning and growth; and

3) Collaborating with them to analyse their own problems, thereby engaging in mutual learning with them

Challenges are provided by:

a) Drawing attention to the complexity of their work and life decisions and discouraging simplistic solutions, 
b) Encouraging them to develop personal authority by listening to their own voices in determining how to live their lives, and

c) Encouraging them to share authority and expertise while working with others to solve mutual problems

(Baxter Magolda, 2009, p. 251).

A well-designed and structured WIL program in tourism higher education could incorporate the three supports and challenges outlined in Baxter Magolda's (2009) Learning Partnerships Model and promote the development of self-authorship. For example, equipping learners with career development knowledge and job search skills to negotiate and secure their own WIL placements affirms the value of their voices and respects their thoughts and feelings. Effective preparation for WIL placements is recognised as a critical stage in WIL to enable students to achieve expected learning outcomes during their placement (Billett, 2011; Jackson, Fleming \& Rowe, 2019). Encouraging self-awareness of values, beliefs and assumptions through study materials and assessments in a pre-internship unit or module is another strategy that educators could utilise to facilitate self-authorship development. Further support for selfauthorship development could be provided through reflective assessments which offer the opportunity for learners to view workplace successes and challenges as opportunities for learning and growth. Assessments, which incorporate presentations to fellow students would facilitate students sharing their personal authority and expertise.

Furthermore, an effective workplace supervisor who treats the learner as a peer during the WIL placement and seeks the learners' input for example, can also provide support in terms of sharing the construction of knowledge (Caldicott \& Wilson, 2017). In reality, not all WIL industry supervisors are effective and supportive mentors (Hall, 
Pascoe \& Charity, 2017). Providing students with the opportunity to analyse critical incidents by articulating their own assumptions and considering other perspectives has been shown to promote intrapersonal and interpersonal development, thus facilitating progression towards self-authorship (Egart \& Healy, 2004). Self-authored individuals use their internal voice to shape reactions and manage external sources (Baxter Magolda, King, Taylor \& Wakefield, 2012). Thus, WIL assessments which provide a safe environment, free from supervisor retaliation, could allow students to strengthen their intrapersonal development.

Often WIL placements occur in unfamiliar settings which can provide challenging situations for students. A curriculum that encourages students to be selfdirected and capable of making their own decisions in the work placement encourages them to act outside of their comfort zone and take personal authority for their learning and actions (Baxter Magolda, 2004). Unfamiliar settings for students undertaking WIL placements in tourism and hospitality organisations can present students with exposure to a range of different cultural perspectives as tourism and hospitality organisations are often comprised of employees from various ethnic backgrounds (Malik, Madappa \& Chitranshi, 2017). Additionally, the customers/guests of internship host organisations are at times international tourists representing a myriad of cultures. Exposure to different cultures can lead to increased awareness, understanding and openness to cultural diversity which have been found to promote self-authorship (King, Baxter Magolda, Barber, Brown \& Lindsay, 2009). Requiring students to articulate how the cultural realities of their WIL placement influenced their personal and professional development could assist in drawing attention to the complexity of their work and life decisions; a challenge deemed necessary in Baxter Magolda's LPM (2009). 
Undoubtedly, WIL offers learners the opportunity to apply theoretical knowledge to practice and develop skills and professionalism, but additionally it can present a provocative moment - believed to be the catalyst for self-authorship development. Fostering self-authorship through WIL in TH\&E programs provides opportunities for students to develop both personally and professionally, with the intention of supporting them in their journey to become the tourism leaders of the future. Developing or re-designing tourism and hospitality education by broadening disciplinary boundaries has been deemed as imperative to meet the needs of the multifaceted tourism and hospitality industries (Hsu, Xiao \& Chen, 2017). This analysis has demonstrated that there is scope for WIL units to be expanded or redesigned beyond vocational and employability goals to meet industry needs while also facilitating the individual, personal development of future tourism, hospitality and events leaders.

\section{Limitations and Future Research}

There are several limitations to this study. The study focused on undergraduate TH\&E degrees offered by public and private universities in Australia only. Whilst the vocational emphasis of tourism and hospitality university programs appears to be similar across various countries, further research analysing TH\&E WIL units in other countries would provide confirmation of this being a global trend.

This study also relied on publicly available unit information guides for data. Some universities did not include complete details about their WIL units. Student learning outcomes were not always included and the association between expected and actual learning outcomes was not investigated. This analysis presented the education institution's perspective. Further research utilising surveys or interviews with students, WIL program coordinators or industry partners could render a deeper and broader understanding. 
This study did provide insights into how WIL units are being used in university tourism and hospitality degrees. Additionally, the study identified the broader scope for the design of WIL units, and how the focus on the students' personal development might be improved so they are better equipped to manage increasingly complex workplaces and lives. 


\section{References}

Airey, D. \& Johnson, S. (1999). The content of tourism degree courses in the United Kingdom. Tourism Management, 20, 229-235.

Airey, D., Tribe, J., Benckendorff, P., \& Xiao, H. (2015). The managerial gaze. Journal of Travel Research, 54(2), 139-151.

Ateljevic, I., Pritchard, A., \& Morgan, N. (Eds.). (2007). The critical turn in tourism studies: Innovative research methodologies. Oxford, UK: Elsevier.

Baker, L., Caldicott, J., \& Spowart, J. (2011). Cooperative and work-integrated education in hospitality and tourism. In R. K. Coll and K. E. Zegwaard (Eds.), International handbook for cooperative and work-integrated education: International perspectives of theory, research and practice (pp. 219-227). Lowell, MA: World Association for Cooperative Education.

Ballantyne, R., Packer, J., \& Axelsen, M. (2009). Trends in tourism research. Annals of Tourism Research, 36(1), 149-152.

Barnett, R. (2000). Super complexity and the curriculum. In M. Tight (ed.) Curriculum in Higher Education. Buckingham: Open University Press.

Barnett, R. (2002). Learning to work and working to learn. In F. Reeve et al. (Eds.), Supporting lifelong learning, Vol. 2: Organizing learning (pp. 7-20). London, UK: Routledge Falmer.

Barnett, R. (2009). Knowing and becoming in the higher education curriculum. Studies in Higher Education, 34(4), 429-440.

Baum, T., Kralj, A., Robinson, R. N., \& Solnet, D. J. (2016). Tourism workforce research: A review, taxonomy and agenda. Annals of Tourism Research, 60, 1-22.

Baxter Magolda, M. B. (2004). Learning partnerships model: A framework for promoting self-authorship. In M. B. Baxter Magolda \& P. M. King (Eds.), Learning 
partnerships: Theory and models of practice to educate for self-authorship, (pp. 37-62). Sterling, VA: Stylus.

Baxter Magolda, M. B. (2009). Authoring your life: Developing an internal voice to navigate life's challenges. Sterling, VA: Stylus.

Baxter Magolda, M. B. (2012). Building learning partnerships. Change, 44(1), 32-38.

Baxter Magolda, M. B., \& King, P. M. (Eds.). (2004). Learning partnerships: Theory and models of practice to educate for self-authorship. Sterling, VA: Stylus.

Baxter Magolda, M. B., King, P. M., Taylor, K. B., \& Wakefield, K. M. (2012). Decreasing authority dependence during the first year of college. Journal of College Student Development, 53(3), 418-435.

Belhassen, Y., \& Caton, K. (2011). On the need for critical pedagogy in tourism education. Tourism Management, 32, 1389-1396.

Billett, S. (2008) Learning to be an agentic professional: Conceptions, curriculum, pedagogy and personal epistemologies. [ilecture] Retrieved from http://learningtobeprofessional.pbworks.com/w/page/15915036/Stephen\%20Billett $\% 20$ presentation

Billett, S. (2011). Curriculum and pedagogic bases for effectively integrating practicebased experiences, ALTC Project Final Report. Retrieved from http://www.altcexchange.edu.au/group/integrating-practiceexperiences-within$\underline{\text { higher-education }}$

Busby, G. (2003). Tourism degree internships: a longitudinal study, Journal of Vocational Education and Training, 55(3), 319-334.

Busby, G. \& Fiedel, D. (2001). A contemporary review of tourism degrees in the United Kingdom. Journal of Vocational Education and Training, 53(4), 501-522. 
Caldicott, J., \& Wilson, E. (2017). Self-authorship development through tourism education: rethinking the outcomes of work-integrated learning. In P. Benckendorff \& A. Zehrer (Eds.), Handbook of Teaching and Learning in Tourism, (pp. 231245). Cheltenham, UK: Edward Elgar Publishing.

Catrett, J. B. (2018). Hospitality Education: A Third Paradigm. In J. Oskam, D. Dekker \& K. Wiegerink (Eds.) Innovation in Hospitality Education (pp. 15-32). Cham: Springer.

Choy, S. (2009). Transformational learning in the workplace. Journal of Transformative Education, 7(1), 65-84.

Chua, K. H., Bakerb, M. A. \& Murrmannc, S. K. (2012). When we are onstage, we smile: The effects of emotional labor on employee work outcomes. International Journal of Hospitality Management, 31, 906-915.

Cockburn-Wootten, C., \& Cockburn, T. (2011). Unsettling assumptions and boundaries: Strategies for developing a critical perspective about business and management communication. Business Communication Quarterly, 74(1), 45-59.

Coll, R.K. \& Eames, C. (2004). International handbook for cooperative education: An international perspective of the theory, research and practice of work-integrated learning. Boston. MA: World Association for Cooperative Education.

Connell, R. (2013). Neoliberalism and Higher Education: The Australian Case. International Sociological Association. Retrieved from http://www.isasociology.org/universities-in-crisis/?p=994.

Connolly, P., \& McGing, G. (2006). Graduate education and hospitality management in Ireland. International Journal of Contemporary Hospitality Management, 18(1), $50-59$. 
Cooper, L., Orrell, J., \& Bowden, M. (2010). Work integrated learning: A guide to effective practice. London: Routledge.

Deloitte Access Economics. (2015). Australian tourism labour force report: 2015-2020. Retrieved from https://www.tra.gov.au/Archive-TRA-Old-site/Research/View-allpublications/All-Publications/australian-tourism-labour-force-report-2015-2020

Dickerson, J. P., \& Kline, S. F. (2008). The Early Career Impact of the Co-op Commitment in Hospitality Curricula. Journal of Teaching in Travel \& Tourism, $8(1), 1-22$.

Dredge, D., Benckendorff, P., Day, M., Gross, M., Walo, M., Weeks, P., \& Whitelaw, P. (2012a). The philosophic practitioner and the curriculum space. Annals of Tourism Research, 39(4), 2154-2176.

Dredge, D., Benckendorff, P., Day, M., Gross, M., Walo, M., Weeks, P., \& Whitelaw, P. (2012b). Building a stronger future: Balancing professional and liberal education ideals in undergraduate tourism and hospitality education: Final report. Retrieved from http://www.tourismhospitalityeducation.info

Dredge, D., Schott, C., Daniele, R., Caton, K., Edelheim, J. \& Munar, A.M. (2015). The tourism education futures initiative. Anatolia, 26(2), 340-346.

Dressler, S., \& Keeling, A. E. (2011). Benefits of cooperative and work-integrated education for students. . In R. K. Coll and K. E. Zegwaard (Eds.), International handbook for cooperative and work-integrated education: International perspectives of theory, research and practice (pp. 41-52). Lowell, MA: World Association for Cooperative Education.

Egart, K., \& Healy, M. P. (2004). An urban leadership internship program: Implementing learning partnerships "unplugged" from campus structures. In M. B. 
Baxter Magolda \& P. M. King (Eds.), Learning partnerships: Theory and models of practice to educate for self-authorship (pp. 125-150). Sterling, VA: Stylus.

Farmaki, A. (2018). Tourism and hospitality internships: A prologue to career intentions? Journal of Hospitality, Leisure, Sport \& Tourism Education, 23, 50-58.

Fletcher, J. K. (1989). Student outcomes: What do we know and how do we know it? Journal of Cooperative Education, xxvi(1), 26-38.

Fletcher, J. K. (1991). Field Experience and Cooperative Education; Similarities and Differences. Journal of Cooperative Education, 27(2), 46.

Francis, R. S. \& Alagas, E. N. (2017). Satisfaction towards internship programmes and future career development for students in private higher education Institutions: A Research Note. Asia- Pacific Journal of Innovation in Hospitality and Tourism, 6(2), 69-74.

Frawley, T., Goh, E., \& Law, R. (2019). Quality assurance at hotel management tertiary institutions in Australia: An insight into factors behind domestic and international student satisfaction. Journal of Hospitality \& Tourism Education, 31(1), 1-9.

Gibson, P. \& Busby, G. (2009). Experiencing work: Supporting the undergraduate hospitality, tourism and cruise management student on an overseas work placement. Journal of Vocational Education and Training, 61(4), 467-480.

Goh, E., Nguyen, S., \& Law, R. (2017). Marketing private hotel management schools in Australia. Asia Pacific Journal of Marketing and Logistics, 29(4), 880-889.

Gribble, N., Dender, A., Lawrence, E., Manning, K., \& Falkmur, T. (2014). International WIL placements: Their influence on student professional development, personal growth and cultural competence. Asia-Pacific Journal of Cooperative Education, 15(2), 107-117. 
Gross, M. J., Benckendorff, P., Mair, J., \& Whitelaw, P. A. (2017). Hospitality higher education quality: Establishing standards in Australia. Journal of Hospitality and Tourism Management, 100(30), 4-14.

Hall, M., Pascoe, D., \& Charity, M. (2017). The Impact of Work-Integrated Learning Experiences on Attaining Graduate Attributes for Exercise and Sports Science Students. Asia-Pacific Journal of Cooperative Education, 18(2), 101-113.

Harper, S., Brown, C., \& Irvine, W. (2005). Qualifications: a fast-track to hotel general manager? International Journal of Contemporary Hospitality Management, 17(1), $51-64$

Higgins-Desbiolles, F. (2006). More than an "industry": The forgotten power of tourism as a social force. Tourism management, 27(6), 1192-1208.

Holborow, M. (2012). Neoliberalism, human capital and the skills agenda in higher education-the Irish case. Journal for Critical Education Policy Studies (JCEPS), 10(1), 93-111.

Hsu, C. H., Xiao, H., \& Chen, N. (2017). Hospitality and tourism education research from 2005 to 2014: "Is the past a prologue to the future?". International Journal of Contemporary Hospitality Management, 29(1), 141-160.

Inui, Y., Wheeler, D., \& Lankford, S. (2006). Rethinking tourism education. Journal of Hospitality, Leisure, Sport and Tourism Education, 5(2), 25-35.

Jackson, D., Fleming, J., \& Rowe, A. (2019). Enabling the Transfer of Skills and Knowledge across Classroom and Work Contexts. Vocations and Learning, 1-20. Johnson, J. L. (2013). Self-authorship in pharmacy education. American journal of pharmaceutical education, 77(4), 69. 
Johnston, J. (2011). Interrogating the goals of work-integrated learning: Neoliberal agendas and critical pedagogy. Asia-Pacific Journal of Cooperative Education, $12(3), 175-182$.

Kegan, R. (1982). The evolving self: Problem and process in human development. Cambridge, MA: Harvard University Press.

Kegan, R. (1994). In over our heads: The mental demands of modern life. Cambridge, MA: Harvard University Press.

Kegan, R. (2000). What "form" transforms? A constructive-developmental approach to transformative learning. In J. Mezirow and Associates (Eds.), Learning as transformation: Critical perspectives on a theory in progress. San Francisco, CA: Jossey-Bass, pp. 35-69.

King, P. M., Baxter Magolda, M. B., Barber, J. P., Brown, M. K., \& Lindsay, N. K. (2009). Developmentally effective experiences for promoting self-authorship. Mind, Brain, and Education, 3(2), 108-118.

Kumar, A. (2007). Personal, Academic and Career Development in Higher Education: Soaring to Success. London \& New York: Routledge, Taylor and Francis.

Lam, T. \& Ching, L. (2007). An exploratory study of an internship program: The case of Hong Kong students. International Journal of Hospitality Management, 26(2), 336-351.

Lee, S. \& Dickson, D. (2010). Increasing student learning in the classroom through experiential learning programs outside the classroom. Journal of Hospitality \& Tourism Education, 22(3), 27-34.

Leslie, D., \& Richardson, A. (2000). Tourism and cooperative education in UK undergraduate courses: are the benefits being realised? Tourism Management, 21(5), 489-498. 
Macquarie University (2019) Create and update unit guides, Retrieved from https://staff.mq.edu.au/teach/learning-technologies-and-spaces/teachingtechnologies-and-tools/iteach/creating-unit-guides

Malik, R., Madappa, T., \& Chitranshi, J. (2017). Diversity management in tourism and hospitality: An exploratory study. Foresight : The Journal of Futures Studies, Strategic Thinking and Policy, 19(3), 323-336.

Mayring, P. (2004). Qualitative content analysis. A companion to qualitative research, $1,159-176$.

Mezirow, J. (Ed.). (2000). Learning as transformation: Critical perspectives on a theory in progress. San Francisco, CA: Jossey-Bass.

Natoli, R., Jackling, B., Kaider, F. \& Clark, C. (2013). Mapping WIL activities in the curriculum to develop graduate capabilities: A case study in accounting. AsiaPacific Journal of Cooperative Education, 14(2), 75-88.

Neuman, L. W. (2011). Social Research Methods (7 $7^{\text {th }}$ ed.). Boston, MA: Pearson Education.

O’Driscoll, F. (2012). What matters most? Quality Assurance in Education, 20(3), 237258.

Orrell, J. E. (2011). Good practice report: Work-integrated learning. Sydney, Australia: Australian Learning \& Teaching Council.

Palmer, S., Young, K., \& Campbell, M. (2018). Developing an Institutional Evaluation of the Impact of Work-Integrated Learning on Employability and Employment. International Journal of Work-Integrated Learning, 19(4), 371-383.

Patrick, C. -J., Peach, D., Pocknee, C., Webb, F., Fletcher, M., \& Pretto, G. (2008). The WIL (Work Integrated Learning) report: A national scoping study (pp. 1-97). 
Strawberry Hills, Australia: Australian Learning and Teaching Council in association with the Australian Collaborative Education Network.

Parks, D. K., Onwuegbuzie, A. J., \& Cash, S. H. (2001). Development of a measure for predicting learning advancement through cooperative education: Reliability and validity of the PLACE scale. Journal of Cooperative Education, 36(1), 23.

Peach, D. \& Matthews, J. (2011). Work Integrated Learning for Life: Encouraging agentic engagement. In Krause, K., Buckridge, M., Grimmer, C. and Purbrick-Illek, S. (Eds.) Research and Development in Higher Education: Reshaping Higher Education, 34 (pp. 227-237). Gold Coast, Australia, 4 - 7 July 2011.

Pizzolato, J. E. (2005). Creating crossroads for self-authorship: Investigating the provocative moment. Journal of College Student Development, 46(6), 624-641.

Poulston, J., \& Jenkins, A. (2016). Barriers to the employment of older hotel workers in New Zealand. Journal of Human Resources in Hospitality \& Tourism, 15(1), 45-68. Raybould, M., \& Wilkins, H. (2005). Over qualified and under experienced: turning graduates into hospitality managers. International Journal of Contemporary Hospitality Management, 17(3), 203-216.

Richardson, S. A. (2008). Undergraduate tourism and hospitality students attitudes toward a career in the industry: A preliminary investigation. Journal of Teaching in Travel \& Tourism, 8(1), 23-46.

Richardson, S. A. (2009). Used and unappreciated: Exploring the role work experience plays in shaping undergraduate tourism and hospitality student's attitude towards a career in the industry. (Doctoral dissertation). Griffith University, Gold Coast.

Ring, A., Dickinger, A., \& Wöber, K. (2009). Designing the ideal undergraduate program in tourism: expectations from industry and educators. Journal of Travel Research, 48(1), 106-121. 
Robinson, R. N., Breakey, N. M., \& Craig-Smith, S. J. (2010). Food for thought: Investigating food and beverage curricular in Australian hospitality degree programs. Journal of Hospitality \& Tourism Education, 22(1), 32-42.

Robinson, R. N., Ruhanen, L., \& Breakey, N. M. (2015). Tourism and hospitality internships: Influences on student career aspirations. Current Issues in Tourism, $19(6), 513-527$.

Rowe, A. D., \& Zegwaard, K. E. (2017). Developing graduate employability skills and attributes: Curriculum enhancement through work-integrated learning. Asia-Pacific Journal of Cooperative Education (Special Issue), 18(2), 87-99.

Sheldon, P. J., Fesenmaier, D. R., \& Tribe, J. (2011). The tourism education futures institute (TEFI): Activating change in tourism education. Journal of Teaching in Travel \& Tourism, 11, 2-23.

Silva, P., Lopes, B., Costa, M., Melo, A., Dias, G. P., Brito, E., \& Seabra, D. (2016). The million-dollar question: Can internships boost employment? Studies in Higher Education, 72(6), 703-721.

Simpson, P., Thyer, L., Van Nugteren, B., Mitchell, G., \& Werner, S. (2016).

Reflections and Experiences of Student Paramedics Undertaking International Work-Integrated Learning Placements. Asia-Pacific Journal of Cooperative Education, 17(2), 187-198.

Sisson, L. G., \& Adams, A. R. (2013). Essential hospitality management competencies: The importance of soft skills. Journal of Hospitality \& Tourism Education, 25(3), $131-145$.

Siu, G., Cheung, C., \& Law, R. (2012). Developing a conceptual framework for measuring future career intention of hotel interns. Journal of Teaching in Travel \& Tourism, 12(2), 188-215. 
Smith, C., \& Worsfold, K. (2014). WIL curriculum design and student learning: a structural model of their effects on student satisfaction. Studies in Higher Education, 39(6), 1070-1084.

Solnet, D., \& Hood, A. (2011). Generation Y as hospitality industry employees: An examination of work attitude differences, Hospitality Training Association, retrieved from www.hta.org.au

Stansbie, P., \& Nash, R. (2016). Customizing internship experiences by emphasis area: The key to increased satisfaction and motivation in hospitality and tourism management students. Journal of Hospitality \& Tourism Education, 28(2), 71-84.

Teng, C. C. (2008). The effects of personality traits and attitudes on student uptake in hospitality employment. International Journal of Hospitality Management, 27(1), $76-86$

Torres, V. (2010). Investigating Latino ethnic identity within the self-authorship framework. In M. B. Baxter Magolda, E. G. Creamer and P.S. Meszaros (Eds.), Development and assessment of self-authorship: Exploring the concept across cultures (pp. 67-84). Sterling, VA: Stylus.

Tribe, J. (2002). The philosophic practitioner. Annals of Tourism Research, 29(2), 338357.

Wang, J., Ayres, H., \& Huyton, J. (2009). Job ready graduates: A tourism industry perspective. Journal of Hospitality and Tourism Management, 16(1), 62-72.

Wang, J., Ayres, H., \& Huyton, J. (2010). Is tourism education meeting the needs of the tourism industry? An Australian case study. Journal of Hospitality \& Tourism Education, 22(1), 8-14. 
Wang, Y., Kitterlin-Lynch, M., \& Williams, J. (2018). Hospitality cooperative education: what are the benefits for industry partners? Journal of Hospitality \& Tourism Education, 30(2), 127-133.

Yiu, M., \& Law, R. (2012). A review of hospitality internship: Different perspectives of students, employers, and educators. Journal of teaching in Travel \& Tourism, 12(4), 377-402.

Zopiatis, A. \& Theocharous, A. L. (2013). Revisiting hospitality internship practices: A holistic investigation. Journal of Hospitality, Leisure, Sport \& Tourism Education, $13,33-46$. 
Table 1. Australian universities offering TH\&E undergraduate degrees.

\begin{tabular}{|c|c|}
\hline Institution & Degree \\
\hline Bond University & Bachelor of Business (Tourism Management) \\
\hline Bond University & Bachelor of International Hotel and Tourism Management \\
\hline $\begin{array}{l}\text { Central Queensland } \\
\text { University }\end{array}$ & Bachelor of Hospitality Management \\
\hline $\begin{array}{l}\text { Charles Sturt } \\
\text { University }\end{array}$ & $\begin{array}{l}\text { Bachelor of Applied Science (Outdoor Recreation and } \\
\text { Ecotourism) }\end{array}$ \\
\hline Curtin University & Bachelor of Commerce (Tourism and Hospitality Major) \\
\hline Deakin University & Bachelor of Management (Event Management) \\
\hline $\begin{array}{l}\text { Edith Cowan } \\
\text { University }\end{array}$ & Bachelor of Business (Tourism \& Hospitality Management) \\
\hline $\begin{array}{l}\text { Edith Cowan } \\
\text { University }\end{array}$ & Bachelor of Hospitality and Tourism Management \\
\hline $\begin{array}{l}\text { Federation } \\
\text { University Australia }\end{array}$ & Bachelor of Management (Tourism) \\
\hline $\begin{array}{l}\text { Federation } \\
\text { University Australia }\end{array}$ & Bachelor of Business (Tourism) \\
\hline Flinders University & $\begin{array}{l}\text { Bachelor of International Tourism Management (Cultural } \\
\text { Tourism) }\end{array}$ \\
\hline Flinders University & $\begin{array}{l}\text { Bachelor of International Tourism Management (Festival and } \\
\text { Event Design and Management) }\end{array}$ \\
\hline Flinders University & $\begin{array}{l}\text { Bachelor of International Tourism Management (Nature } \\
\text { Based Tourism) }\end{array}$ \\
\hline Griffith University & $\begin{array}{l}\text { Bachelor of International Tourism and Hotel Management } \\
\text { (Tourism Management) }\end{array}$ \\
\hline Griffith University & $\begin{array}{l}\text { Bachelor of International Tourism and Hotel Management } \\
\text { (Hospitality Management) }\end{array}$ \\
\hline $\begin{array}{l}\text { James Cook } \\
\text { University }\end{array}$ & $\begin{array}{l}\text { Bachelor of Business in Hospitality and Tourism } \\
\text { Management }\end{array}$ \\
\hline La Trobe University & Bachelor of Business (Tourism and Hospitality) \\
\hline Murdoch University & Bachelor of Arts (Tourism and Events) \\
\hline
\end{tabular}




\begin{tabular}{|c|c|}
\hline Murdoch University & $\begin{array}{l}\text { Bachelor of Business in Hospitality and Tourism } \\
\text { Management }\end{array}$ \\
\hline $\begin{array}{l}\text { Southern Cross } \\
\text { University }\end{array}$ & Bachelor of Business in Convention and Event Management \\
\hline $\begin{array}{l}\text { Southern Cross } \\
\text { University }\end{array}$ & $\begin{array}{l}\text { Bachelor of Business in Tourism and Hospitality } \\
\text { Management }\end{array}$ \\
\hline $\begin{array}{l}\text { Southern Cross } \\
\text { University }\end{array}$ & Bachelor of Business in Hotel Management \\
\hline $\begin{array}{l}\text { Swinburne } \\
\text { University of } \\
\text { Technology }\end{array}$ & Bachelor of Business (Tourism Management) \\
\hline $\begin{array}{l}\text { University of } \\
\text { Canberra }\end{array}$ & $\begin{array}{l}\text { Bachelor of Business Studies (Event and Tourism } \\
\text { Management) }\end{array}$ \\
\hline $\begin{array}{l}\text { University of } \\
\text { Canberra }\end{array}$ & Bachelor of Event and Tourism Management \\
\hline $\begin{array}{l}\text { University of } \\
\text { Newcastle }\end{array}$ & Bachelor of Business (Tourism Major) \\
\hline $\begin{array}{l}\text { University of } \\
\text { Newcastle }\end{array}$ & Bachelor of Social Science (Tourism Major) \\
\hline $\begin{array}{l}\text { University of } \\
\text { Queensland }\end{array}$ & Bachelor of International Hotel and Tourism Management \\
\hline $\begin{array}{l}\text { University of South } \\
\text { Australia }\end{array}$ & Bachelor of Business (Tourism and Event Management) \\
\hline $\begin{array}{l}\text { University of } \\
\text { Southern } \\
\text { Queensland }\end{array}$ & Bachelor of Business (Tourism and Events Management) \\
\hline $\begin{array}{l}\text { University of } \\
\text { Southern } \\
\text { Queensland }\end{array}$ & Bachelor of Business (Tourism Management) \\
\hline $\begin{array}{l}\text { University of } \\
\text { Tasmania }\end{array}$ & Bachelor of Business Administration (Tourism Management) \\
\hline $\begin{array}{l}\text { University of } \\
\text { Technology, Sydney }\end{array}$ & $\begin{array}{l}\text { Bachelor of Management (Tourism Major/ Sport } \\
\text { Major/Event Major) }\end{array}$ \\
\hline $\begin{array}{l}\text { University of the } \\
\text { Sunshine Coast }\end{array}$ & $\begin{array}{l}\text { Bachelor of Business (Tourism, Leisure and Event } \\
\text { Management) }\end{array}$ \\
\hline $\begin{array}{l}\text { University of } \\
\text { Wollongong }\end{array}$ & Bachelor of Commerce (Tourism Management) \\
\hline
\end{tabular}




\begin{tabular}{|l|l|}
\hline Victoria University & Bachelor of Business (International Tourism Management) \\
\hline $\begin{array}{l}\text { Western Sydney } \\
\text { University }\end{array}$ & $\begin{array}{l}\text { Bachelor of Business and Commerce (Hospitality } \\
\text { Management) }\end{array}$ \\
\hline $\begin{array}{l}\text { Western Sydney } \\
\text { University }\end{array}$ & Bachelor of Social Science (Heritage and Tourism) \\
\hline $\begin{array}{l}\text { Western Sydney } \\
\text { University }\end{array}$ & Bachelor of Tourism Management \\
\hline
\end{tabular}

Table 2: Unit description themes (cited 10 or more times). NB: Total $\mathrm{N}$ does not equal 100 .

\begin{tabular}{|l|l|}
\hline Theme & n \\
\hline Career related & 48 \\
\hline Application of knowledge and skills to practice & 42 \\
\hline Authentic & 36 \\
\hline Acquire professional attitudes & 31 \\
\hline Project & 14 \\
\hline Placement & 14 \\
\hline Team work & 11 \\
\hline Self-awareness & 11 \\
\hline Develop generic skills & 11 \\
\hline Reflection on learning process & 11 \\
\hline Acquire knowledge & 10 \\
\hline
\end{tabular}

Table 3: Unit content themes (cited 10 or more times). NB: Total $\mathrm{N}$ does not equal 100.

\begin{tabular}{|l|l|}
\hline Theme & n \\
\hline Careers / employability & 41 \\
\hline Professionalism / Professional practice & 20 \\
\hline Communication & 17 \\
\hline Reflection on performance & 16 \\
\hline Workplace planning/management & 13 \\
\hline Application of coursework to practice & 13 \\
\hline Authentic professional environment & 12 \\
\hline Critically evaluate & 11 \\
\hline
\end{tabular}

Table 4: Unit learning outcome themes (cited 10 or more times). NB: Total $\mathrm{N}$ does not equal 100. 


\begin{tabular}{|l|l|}
\hline Theme & $\mathbf{n}$ \\
\hline Professional conduct / development & 30 \\
\hline Career & 27 \\
\hline Apply discipline specific knowledge to practice & 24 \\
\hline Reflection & 13 \\
\hline Communication & 12 \\
\hline Business environment awareness & 11 \\
\hline
\end{tabular}

